\title{
Specialized Dictionary Mobile Apps for Students Learning English for Engineering, Business and Computer Science
}

\author{
Prof. Reima Al-Jarf \\ King Saud University, Riyadh, Saudi Arabia \\ ORCID ID: 0000-0002-6255-1305 \\ email: reima.al,jarf@gmail.com
}

Accepted: 08 Jan 2022; Published: 14 Jan 2022

(C)2022 The Author(s). Published by TheShillonga. This is an open access article under the CC BY license (https://creativecommons.org/licenses/by/4.0/)

\begin{abstract}
Use of dictionaries is an integral part of language learning and teaching. With the availability of smartphones, EFL, ESL and ESP students can access and download a variety of specialized mobile dictionaries Apps (MDAs). Specialized MDAs are of special importance for students learning English for engineering, business, and computer science purposes. They contain thousands of essential specialize technical terms covering several sub-categories within the engineering, business and computer science fields. They are a good tool for enriching the students' specialized vocabulary and helping them learn faster and remember more in a shorter time. This article aims to show ESP instructors examples of engineering, computer science and business MDAs available in the Google Play or Apple Stores; how specialized MDAs can be located; criteria for selecting specialized MDAs; the lexicographical features of specialized MDA and instructional stages with MDAs. Instruction with MDAs goes through three stages: pre-task, task, and post-task phases. The instructor serves as a facilitator. She can help students find and download MDAs that meet their needs and purposes and match their proficiency level; gives pre-questions; and follows the students up to make sure they are making the best use of MDAs. The article concludes with some recommendations for ESP pedagogy with MDAs.
\end{abstract}

Keywords - Specialized dictionaries, mobile dictionary apps, engineering dictionary apps, business dictionary apps, computer science dictionary apps.

\section{INTRODUCTION}

In this day and age, smart phones are loaded with educational applications that students of all ages and all fields of study can use for a variety of purposes, including foreign/second language learning. A variety of language learning apps are available in the Android and Apple Stores for developing English as a Foreign Language (EFL), English as a Second Language (ESL), and English for Specific Purposes (ESP) students' listening and speaking skills [1]; [2]; [3]; listening to and pronouncing new vocabulary based on first language (L1) to second language (L2) translation [4]; reading skills and literature [5]; [6]; [7]; [8]; writing skills [9]; vocabulary learning [10]; enhancing students' incidental vocabulary learning in English-medium universities through the use of Personal Digital Assistants (PDAs) [11]; standardized tests [12]; learning English by children on smart phones, iPads, and tablets [13]; [14]; and general language learning purposes [15] [16]; [17]; [18].
As for dictionaries, students have been using monolingual, and bilingual, general, and specialized print (paper) dictionaries in learning L1 and L2 for a very long time [19]. They used them to look up the meanings of difficult words in general as well as specialized contexts. When portable (handheld) electronic dictionaries appeared over 2 decades ago, students started to use them and bring them to class instead of carrying heavy paper dictionaries. Students majoring in languages and translation used portable (handheld) electronic dictionaries for a variety of purposes such as obtaining definitions of general and specialized terminology, Arabic equivalents of English words and English equivalents of Arabic words, a variety of word senses, synonyms, pronunciation, part of speech, spelling variants, derivatives, verb conjugation, usage and grammar notes and illustrative examples [20]; [21]. Soon, many monolingual and bilingual, general, and specialized dictionaries in many languages started to have an online 
version [17]; [22]. There are even dictionary websites that host numerous dictionaries in one location such as www.onelook.com in English, and www.almaany.com in Arabic. Further development in digital dictionaries have occurred in the past decade or so, with the creation and widespread use of mobile apps for almost every traditional dictionary such as Webster, Cambridge, Longman, Collins, and McMillan. Those can be accessed from any smart mobile phone, iPad, or tablet.

Due to the importance of digital, online dictionaries and mobile dictionary apps (MDAs) in language learning, a review of the literature has shown numerous studies that highlighted the benefits of using MDAs in language learning such as learning Chinese, Turkish and English as a foreign language. For example, in China, secondary school students in rural areas use smartphones, followed by portable electronic dictionaries, tablets and laptops in informal learning of English [23]. Similarly, students learning Turkish as a foreign language most often use Google Translate and Turkish English mobile dictionaries. The students' interest level in using mobile dictionaries was rated 'good' [24]. At an Australian university, [25] found that all students enrolled in language courses across ten languages in the first-, second- and third-year level use electronic dictionaries to look up unknown words or obtain translations. Many students' comments reflected their knowledge of the effective use of electronic dictionary tools and awareness of their limitations.

In Hong Kong, [26] found that MBAs are essential tools that help college students in L2 learning and in academic studies. Bilingual dictionaries with multiple functions and rich resources help the students engage in learning the subject courses and learn English at the same time. However, discrepancies exist in the students' actual and desired use of dictionary functions. Undergraduate students in Taiwan, who used handheld electronic dictionaries to learn English, reported that those dictionaries were useful and fun. Use of handheld electronic dictionaries positively correlated with students' satisfaction with English mobile learning. Self-management of learning could moderate the relationships between key mobile English learning determinants, satisfaction, and continued intention [27]. Moreover, [28] found that students had positive attitudes and emotions toward mobile learning, consisting of anticipation, joy, surprise, and trust. However, there were negative emotion of apprehension and anxiety while communicating in a foreign language.

A second line of research investigated the effects of using digital, electronic, and mobile dictionaries on vocabulary acquisition in L2. At Amirkabir University of Technology, in Iran, dictionary and lexical apps are very popular among students. The students find them useful in language learning but there are different viewpoints on the potential of mobile apps for developing different language skills. The type of apps used significantly shaped students' attitudes towards app-based language learning [29]. In Hong Kong, mobile dictionaries facilitated incidental word learning significantly through consulting mobile dictionaries while reading [30]. At Al-Najah National University, in Nablus, Palestine, students enrolled in educational readings in English at the Faculty of Social Sciences and Teacher Training had a great and exciting experience in using mobile dictionaries for learning new vocabulary. The students also had positive attitudes towards mobile dictionaries [31].

A third line of research compared some dictionary types and the effects of teaching strategies on vocabulary learning. A study by [32] investigated the effects of types of dictionaries used on lexical proficiency in writing by intermediate level students preparing for the TOEFL. Bilingual English-Persian Desk Dictionaries were the most frequently used, whereas Bilingual Persian-English Desk Dictionary and Bilingual Persian-English Mobile Dictionary were the least favoured dictionaries among the students. Consulting dictionaries to obtain meaning during the reading-writing, and after listening-speaking tasks were the most common habits among the students. There was a significant correlation between the dictionary type used and students' lexical proficiency in writing and between students' skill in dictionary use and their lexical proficiency in writing.

Another study by [33] compared the influence of electronic dictionaries vs. paper dictionaries on vocabulary learning and retention of Iranian EFL students. Results indicated that students in the electronic dictionary group outperformed those of the paper dictionary group. It was concluded that electronic dictionaries can improve vocabulary learning.

In a third study by [34], freshman students with upper intermediate proficiency level were taught 320 head words from the Academic Word List via SMS, whereas the control group was taught the same words using a dictionary. Both groups made improvements with no significant difference between them in the post-test scores. However, on the delayed post-test, the experimental group outperformed the control group, i.e., SMS learning had a more significant effect on vocabulary retention than dictionary usage. The researchers recommended that language instructors use SMS as a useful way to help students retain vocabulary items in their long-term memory.

Furthermore, the literature review has shown that despite the widespread growth in the use of smartphones, 
iPads and tablets, which have facilitated a plethora of new mobile language learning applications in all languages especially English, there is still a dearth of studies that investigate the utilization of specialized MDAs in the teaching of English for engineering, business and computer science purposes at colleges of science and technology such as the Ibri College of Technology in Oman. In this respect, [33] indicated that vocabulary learning needs special teaching strategies and language learning process. The use of dictionaries is a great help in vocabulary learning and the emergence of electronic dictionaries has added a new and valuable resource for vocabulary learning. Mobile phone apps are a new addition to information and communication technologies which have created new ways to help students in learning specialized technical terminology in engineering, business, and computer science. [30] added that although the dictionary format is significant, dictionary training is indispensable.

At colleges of technology, students studying English for engineering, business and computer science purposes usually focus on their assigned textbooks and many are not familiar with relevant engineering, business, and computer science MDAs. Many instructors teaching English for engineering, business and computer science purposes are specialized in English or linguistics but they are not familiar with engineering, business and computer science MDAs in those areas of specialty, and do not know how to integrate them in teaching English to freshman students majoring in engineering, business and computer science.

Since ESP instructors play an important role in guiding students' lexical learning of specialized technical terms, this study aims to introduce ESP instructors to: (i) the types of engineering, business, and computer science MDAs, their lexicographical features, different learning modes, and how words can be located, browsed, learnt and revised; (ii) the benefits of using MDAs; (iii) how to search MDAs; (iv) criteria for selecting engineering, business, computer science MDAs; (v) stages of teaching with engineering, business, computer science MDAs; and (vi) the ESP instructor's role in training students to use specialized MDAs.

This study is significant because specialized MDAs are a well-established aid for learning English technical terms in the students' area of specialization. Many students learning English for engineering, business and computer in English-medium colleges and universities struggle when they have to learn specialized technical terms, facts, or fundamental concepts in English. In some cases, students taking ESP courses are even unsure about what they should study and how they can broaden their knowledge of technical terms. The students can use a multitude of specialized MDAs at their own convenience for free. Even ESP instructors with little knowledge in engineering, business or computer science can acquire specialized technical terms in those areas by searching MDAs.

\section{WHY USE SPECIALIZED MOBILE DICTIONARY APPS}

Students learning English for engineering, business, or computer science purposes can enrich their technical terms in their area of specialization by using MDAs specialized in engineering, business, or computer science as these contain thousands of technical terms. A variety of specialized MDAs in a specific area exist which students of different proficiency levels (beginners, intermediate and advanced) can use. ESP students can check the meanings of difficult technical terms in a short time. They learn faster and remember more. The students can use specialized MDAs for self-testing. They can check their MDAs anywhere, anytime and as many times as they need.

\section{SEARCHING FOR ENGINEERING, BUSINESS AND COMPUTER SCIENCE MDAS}

The instructor may search the Google Play and/or Apple App Stores for engineering, business or computer science MDAs targeting a specific area of specialization within the general field by selecting specific search terms such as "engineering dictionaries", "civil engineering dictionaries", "business dictionaries", "economics dictionaries", "computer dictionaries", "information technology dictionaries" and so on. She can enclose the search terms in quotation marks, and use Boolean operators (\&, or, not) to narrow the search. It is important to add "English" in order to get more accurate results and to avoid getting MDAs in other languages. Once a search term is entered in the search box, Google Play will suggest related search terms that can be tried. The students can also locate, select, and suggest MDAs for specific sub-fields such as:

- Engineering: mechanical, electrical, chemical, environmental, electronics, software, architectural, petroleum, mining, biochemical, biomedical, biomolecular, environmental, food, genetic, materials science, petroleum, plastics, textile, construction, telecommunications, geotechnical, structural, mechatronics, microelectronic, optical, robotics, electronics, transportation, power systems, aeronautical, aerospace, agricultural, astronautical, automotive, energy, marine, manufacturing, power plant, renewable energy, thermal, industrial engineering and others. 
- Business: management, economics, finance, logistics, planning, corporate, accounting, marketing, human resources, banking, international business, hotel management, e-commerce, e-business, hospital administration, entrepreneurship, supply chain management, project management, data analysis, investments and securities, logistics.

- Computer Science: software, programming, telecommunications, networking, network security, information security, information technology, information systems, information science, artificial intelligence, computer software and applications, computer systems networking, data processing, data mining, computer information systems. hardware engineering.

For examples of MDAs in engineering, business and computer science, see Images 1, 2, 3 in the Appendix.

\section{FEATURES OF SPECIALIZED ENGINEERING, BUSINESS AND COMPUTER SCIENCE MDAS}

Specialized MDAs have a letter index, a category index, or an alphabetical index. Students can enter the term they want look up in the search box or they can browse the list of terms under a particular letter. They may also search in a particular category. Some MDAs have a tutorial, a guide, videos, quizzes and/or "Term of The Day". Some business MDAs have a loan calculator. Specialized MDAs generally give the definition of a technical term or an acronym. The students can also enter a letter in the search box and get an alphabetical list of the technical terms that begin with that letter, browse through the list and select the term they are looking for. The students can bookmark the words which they have looked up and would like to save for later. They can use the quizzes to assess their vocabulary knowledge or learning, or retention (See Images 4, 5, 6, 7, 8 in the Appendix).

On the other hand, specialized MDAs have some shortcomings such as: having ads, giving the definition of the term only, not showing how a term is pronounced, not giving the part of speech nor other words derived from the term. In some specialized MDAs, the students have to enter the word they are looking for and may not find it if they misspell it and they do not see a list of options in alphabetical order. In many MDAs there are no illustrations to clarify the meaning especially in engineering dictionaries.

\section{CRITERIA FOR SELECTING ENGINEERING, BUSINESS AND COMPUTER SCIENCE MDAS}

The MDAs selected should be related to the students' area of specialty. The instructor can download several MDAs, that target a particular subspecialty to accommodate the students' different proficiency levels, interests, needs, learning styles and even to be familiar with different MDA designs and content. MDAs chosen should contain enough material for practice. The instructor should take into consideration the difficulty level of the terms within the MDA, degree of familiarity and complexity and content details. The instructor can look at the MDAs star ratings and read the users' reviews and comments. She may try several MDAs in an engineering, business, or computer science sub-specialty before deciding which ones are useful and appropriate for the students. She can select those that are free of charge and easy to use by the students.

\section{INSTRUCTIONAL STAGES WITH SPECIALIZED MDAS}

Instruction with MDAs goes through 3 phases. In the PreTask Phase, the instructor tells the students which MDAs they need to locate, download, and use. She shows the students how to search Google Play or the Apple App Stores for specialized MDAs targeting a specific area of specialty. She tells the students about the MDAs to be used. She posts a sample of MDAs on a Learning Management System (LMS) such as Microsoft Teams, Zoom, Google classroom, Blackboard, a blog, an online discussion forum, on Facebook, Twitter, WhatsApp, or Telegram. She states the objective of using the MDAs, i.e., tells the students what they are going to do, study or practice and how they are going to use the MDAs. She gives clear, specific, and detailed instructions on how a particular task should be performed. She tells the students what is expected of them, how many MDAs they need to complete and sets a deadline for completing the assigned MDAs.

In the Task Phase, the students work with the MDAs on their smart phones, tablet, or laptop at home or in class. They work on MDAs individually, in pairs or small groups. They post queries, comments, and evaluations of the MDAs they have used on an LMS or a social media network. The instructor answers students' questions, provides guidance, and help with difficulties.

In the Post Task Phase, the ESP instructor gives feedback and comments on the students' performance. She encourages the students to use specialized MDAs in their area of specialization and gives credit for using them. The students correct their classmates' errors and make comments on each other's performance. They keep a log of 
the MDAs they have used with their evaluation of and comments on each.

\section{THE ESP INSTRUCTOR'S ROLE}

The ESP instructor serves as a facilitator. She helps the student enrolled in English for engineering, business, or computer sciences courses in locating and downloading relevant MDAs that meet their needs and purposes. She matches the students' English proficiency level with the specialized MDAs difficulty level. She encourages the students to fully engage in the MDA activities. She follows the students up to make sure they are making the best use of the MDAs. She gives extra credit for using MDAs in their ESP courses depending on how many they have completed. Technical terms learnt from MDAs may be included on ESP tests to motivate the students to take the MDA activities seriously.

\section{RECOMMENDATIONS}

ESP instructors teaching English for engineering, business and computer science purposes should exploit latest advancements in mobile technology to help ESP students develop their English proficiency level and learn how to search specialized MDAs. Specialized MDAs allow students to use their visual and auditory senses to learn difficult technical terms. ESP instructors should always remember that MDAs do not teach by themselves, and their use does not guarantee the automatic learning and recall of the specialized technical terms. ESP instructors should encourage their students to engage in, respond to, and be actively involved in activities with MDAs. They should supervise students, give them feedback, guide them, and encourage them. Students may use specialized MDAs of their choice. Those who do not own a smart phone may access specialized online dictionaries using their laptop computer.

To make the best use of MDAs, the ESP instructor may integrate different elements of word knowledge with online word activity designs, direct instruction on specific technical terms, and students' awareness of specialized term selection. To make technical term and content technical learning more effective, the students can browse and locate terms of interest to them on their own. Since ESP students' satisfaction, perceived difficulty of MDAs and level of control over MDAs affect their performance, selected specialized MDAs should have a variety of formats and designs. ESP instructors can prepare a taxonomy of available MDAs in a specific area together with their use for language learning based on the students' experience. ESP instructors can enhance students specialized lexical competence by modifying the type of MDAs they use, understanding students' choice of MDAs, and their habits in using MDAs.

The utilization of different MDA formats by students learning English for engineering, business, or computer science together with their preference and views on their usefulness in specific contexts, are still open for further investigation by researchers in the future.

\section{REFERENCES}

[1] Al-Jarf, R. (2021e). Mobile audiobooks, listening comprehension and EFL college students. International Journal of Research - GRANTHAALAYAH, 9(4), 410-423. https://doi.org/10.29121/granthaalayah.v9.i4.2021.3868 DOI: $10.2139 / \mathrm{ssrn} .3841694$

[2] Al-Jarf, R. (2021g). TED talks as a listening resource in efl college classrooms. International Journal of Language and Literary Studies (ijlls), 2(3), 256-267. https://doi.org/10.36892/ijlls.v2i3.691.

https://ijlls.org/index.php/ijlls/article/view/691. ERIC ED615127.

[3] Al-Jarf, R. (2012). Mobile technology and student autonomy in oral skill acquisition. In J. E. Díaz Vera (Ed), Left to My Own Devices: Innovation and Leadership in English Language Teaching. 105-129. Brill. https://doi.org/10.1163/9781780526478_007

[4] Zubenko, T. \& Shwedel, A. (2019). Integrating mobile listening and physical activity to facilitate intentional and incidental vocabulary acquisition. Advanced Education, 11, 84-92.

[5] Al-Jarf, R. (2021c). Collaborative mobile ebook reading for struggling EFL college readers. IOSR Journal of Research \& Method in Education (IOSR-JRME), 11(06), 32-42. DOI: $10.9790 / 7388-1106023242$. Accessed from https://www.iosrjournals.org/iosr-jrme/papers/Vol11\%20Issue-6/Ser-2/D1106023242.pdf

[6] Al-Jarf, R. (2016). Enhancing reading and speaking skills in EFL through multicultural literature. Asian Academic Journals of Social Sciences and Humanities (AAJSSH), 3(7) (July), 288-298.

[7] Al-Jarf, R. (2015). Enhancing reading and speaking skills in EFL through multicultural children's short stories. 7th International Conference Building Cultural Bridges (ICBCB), Almaty, Kazakhstan, April 23-24, 2015. ERIC ED610158. https://doi.org/10.2139/ssrn.3848464

[8] Hazaea, A. \& Alzubi, A. (2016). The effectiveness of using mobile on EFL learners' reading practices in Najran University. English Language Teaching, 9(5),8-21.

[9] Al-Shehab, M. (2020). The role of mobile-assisted language learning (MALL) in enhancing the writing skills of intermediate IEP Students: expectations vs reality. Language Teaching Research Quarterly, 20, 1-18.

[10] Kohnke, L. \& Ting, A. (2021). ESL students' perceptions of mobile applications for discipline-specific vocabulary acquisition for academic purposes. Knowledge Management \& E-Learning, 13(1), 102-117. 
[11] Song, Y. \& Fox, R. (2018). Using PDA for undergraduate student incidental vocabulary testing. ReCALL, 20(3), 290314.

[12] Al-Jarf, R. (2021f). Standardized test preparation with mobile flashcard apps. United International Journal for Research \& Technology (UIJRT), 3(2), 33-40. https://uijrt.com/paper/standardized-test-preparation-withmobile-flashcard-apps.

[13] Al-Jarf, R. (2021b). Differential effects of the iPad on first and second language acquisition by Saudi children during the Covid-19 pandemic. The $17^{\text {th }}$ International Scientific Conference eLearning and Software for Education (eLSE), Bucharest, Romania. Vol. 1, pp. 96-105. DOI: 10.12753/2066-026X-21-013.

[14] Al-Jarf, R. (2021d). Impact of the iPad on Saudi young children in the home environment as perceived by their mothers. International Journal of Research in Engineering, IT and Social Sciences (IJREISS), 11(2), 26-35, (FEB). ERIC ED613057.

[15] Al-Jarf, R. (2021a). Blind Saudi female college students and assistive technologies: A case study. International Journal of Research in Engineering, IT and Social Sciences (IJREISS), 11(4), 1-9. ERIC ED613224. Accessed from http://indusedu.org/pdfs/IJREISS/IJREISS_3780_72724.pd $\mathrm{f}$

[16] Al-Jarf, R. (2020a). Mobile apps in the EFL college classroom. Journal for Research Scholars and Professionals of English Language Teaching (JRSP-ELT), 4(22),1-5. ERIC ED613138.

[17] Al-Jarf, R. (2020b). Arabic digital dictionaries. Eurasian Arabic Studies, 12(Dec), 16-42. Accessed from https://cyberleninka.ru/article/n/arabic-digital-dictionaries.

[18] Ibrahim, A. \& Kadiri, G. (2018). Integrating mobile phones in teaching auditory and visual learners in an English classroom. English Language Teaching, 11(12), 1-10.

[19] Al-Jarf, R. (1998). Dictionary skills for translation students. https://www.researchgate.net/publication/348602404

[20] Al-Jarf, R. (2001). Electronic Dictionaries in Translation Classrooms in Saudi Arabia. Linguistica Communicatio, 10, 27-134. ERIC ED613066.

[21] Al-Jarf, R. (1999). Electronic dictionaries in ESL classrooms.5th Annual TESOL Arabia Conference on 'Teaching Learning and Technology', 4, 42-51. ERIC ED613205.

[22] Al-Jarf, R. (2014). Online Arabic-English-Arabic specialized dictionaries. In M. Ángel Campos and J. Ramón Calvo's (Eds), Investigating Lexis: Vocabulary Teaching, ESP, Lexicography and Lexical Innovations. Cambridge Scholars Publishing. 95-102. http://www.cambridgescholars.com/investigating-lexis
[23] Guo, J., Huang, F., Lou, Y. \& Shaomei, C. (2020). Students' perceptions of using mobile technologies in informal English learning during the COVID-19 epidemic: A study in Chinese rural secondary schools. Journal of Pedagogical Research, 4(4), 475-483.

[24] Baskin, S. \& Yildirim, A. (2020). Interest levels on using mobile dictionaries of students learning Turkish as a foreign language in Turkey. African Educational Research Journal, 8(2), 279-286.

[25] Levy, M. \& Steel, C. (2015). Language learner perspectives on the functionality and use of electronic language dictionaries. ReCALL, 27(2), 177-196.

[26] Ma, Q. (2019). University L2 learners' voices and experience in making use of dictionary apps in mobile assisted language learning (mall). international journal of computer-assisted language learning and teaching, 9(4), Article 2, 18-36.

[27] Huang, R. (2014). Exploring the Moderating Role of SelfManagement of Learning in Mobile English Learning. Educational Technology \& Society, 17(4), 255-267.

[28] Ilic, P. (2020). Sentiment analysis of students' attitudes toward mobile learning activities. 28th EUROCALL Conference. ERIC ED611125.

[29] Nami, F. (2020). Educational smartphone apps for language learning in higher education: students' choices and perceptions. Australasian Journal of Educational Technology, 36(4), 82-95.

[30] Zou, D., Xie, H. \& Wang, F. L. (2015). The use of monolingual mobile dictionaries in the context of reading by intermediate Cantonese EFL learners in Hong Kong. 22nd EUROCALL Conference, Padova, Italy.

[31] Barham, K. A. (2017). The use of electronic dictionary in the language classroom: The views of language learners. 2nd International Conference for Learning and Teaching in the Digital World. Nablus, Palestine. ERIC ED573437.

[32] Vahdany, F., Abdollahzadeh, M., Gholami, S. \& Ghanipoor, M. (2014). A study of the relationship between type of dictionary used and lexical proficiency in writings of Iranian EFL students. Advances in Language and Literary Studies, $5(6), 31-38$.

[33] Rezaei, M. \& Davoudi, M. (2016). The influence of electronic dictionaries on vocabulary knowledge extension. Journal of Education and Learning, 5(3), 139-148.

[34] Alemi, M., Sarab, M. R. \& Lari, Z. (2012). Successful learning of academic word list via MALL: mobile assisted language learning. International Education Studies, 5(6), 99-109. 


\section{APPENDIX}

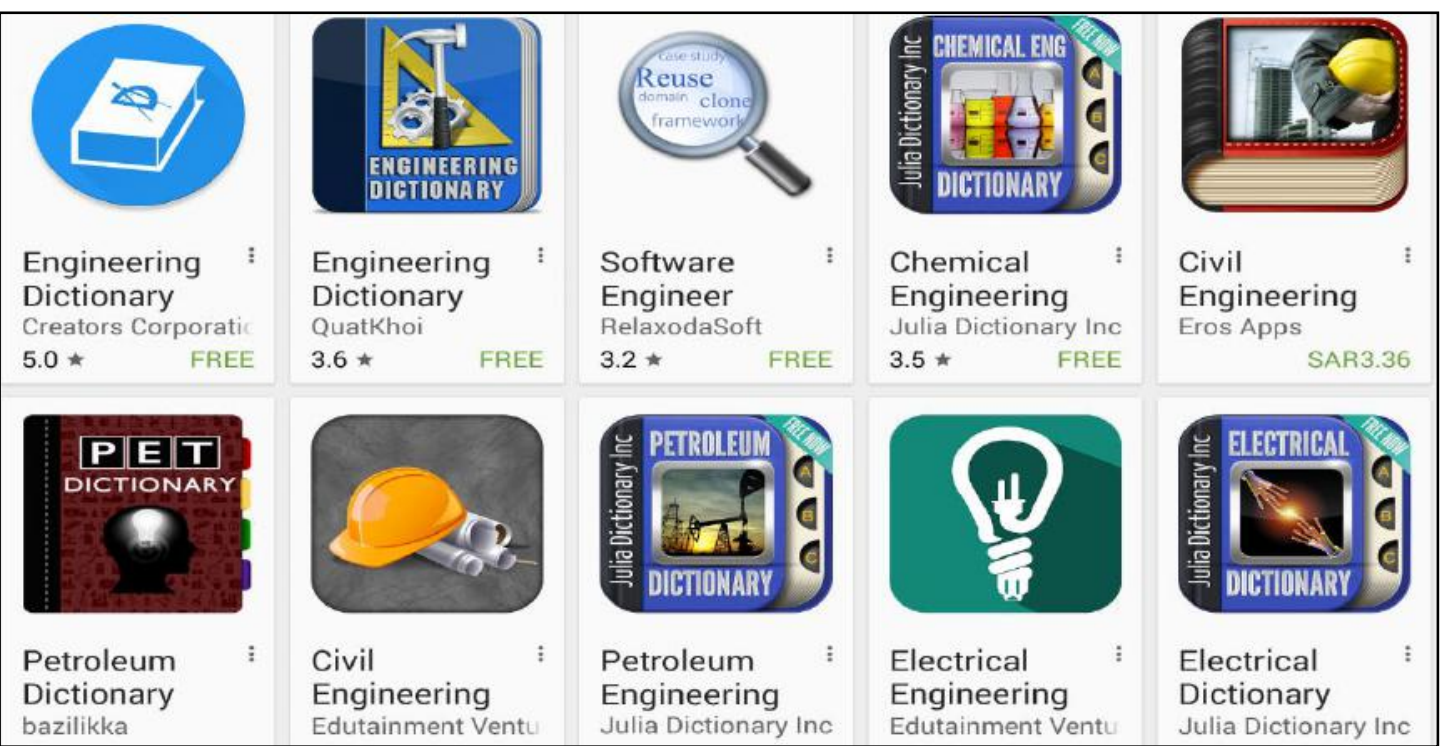

Image 1: Examples of Engineering Mobile Dictionary Apps

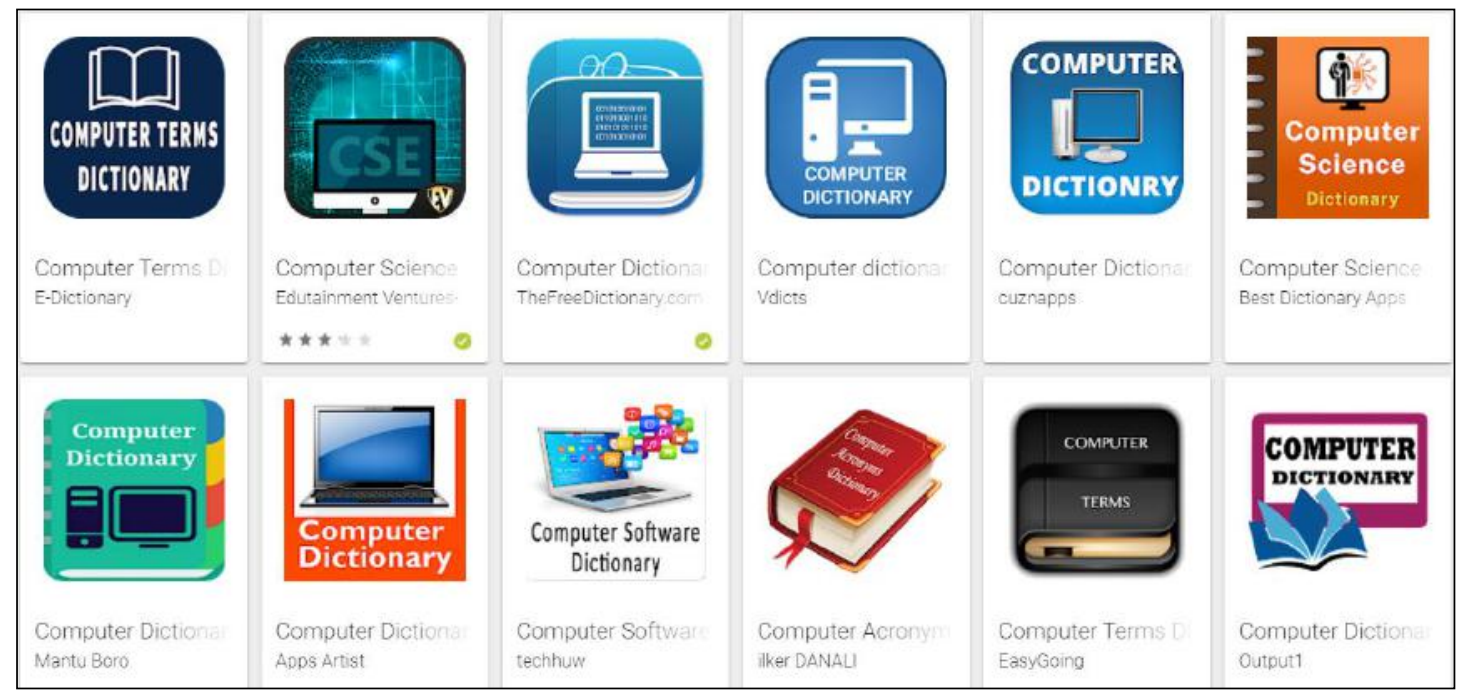

Image 2: Examples of computer Science Mobile Dictionary Apps

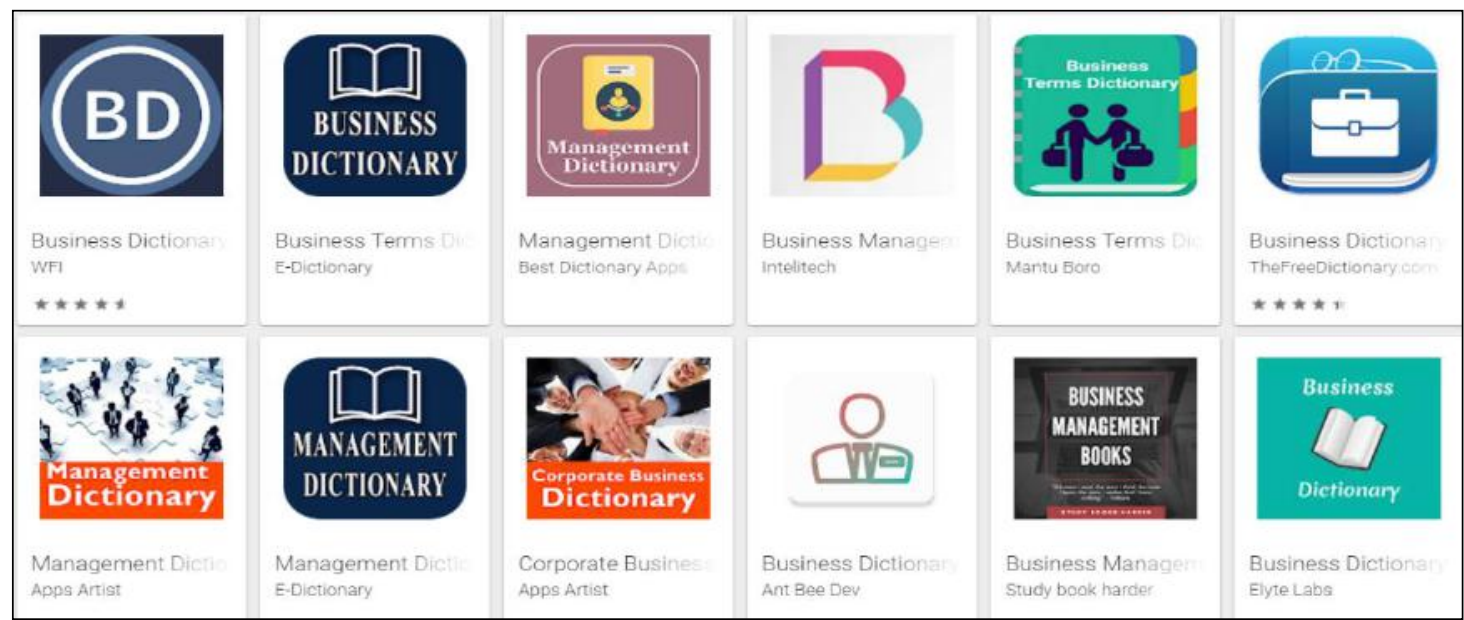

Image 3: Examples of Business Mobile Dictionary Apps 


\begin{tabular}{|c|c|c|}
\hline$\leftarrow$ & $\begin{array}{l}\text { Basic Engineering } \\
\text { Categories }\end{array}$ & Iy \\
\hline [त्र] & Automobile Engineering & $>$ \\
\hline$\Gamma$ & Hydraulics & $>$ \\
\hline- & Aluminium And Metals & $>$ \\
\hline$x$ & Principles And Standards & $5>$ \\
\hline *3 & Tools \& Technology & $>$ \\
\hline 要 & Networking & $>$ \\
\hline 步 & Software Engineering & $>$ \\
\hline & & \\
\hline & E & \\
\hline
\end{tabular}

\begin{tabular}{|ll|}
\hline $\begin{array}{l}\text { Basic Engineering } \\
\text { Quick Guide }\end{array}$ & (y) \\
\hline Circuit Symbols & $1>$ \\
\hline Electronic Formulas & $2>$ \\
\hline Resistor Networks & $3>$ \\
Alternating Current & $4>$ \\
Ohmis Law & $5>$ \\
Capacitor Networks & $5>$ \\
Mathematics & $6>$ \\
Algebraic Transposition & $7>$ \\
\hline Law of Exponents & $7>$ \\
\hline Common Logarithms & $7>$ \\
\hline
\end{tabular}

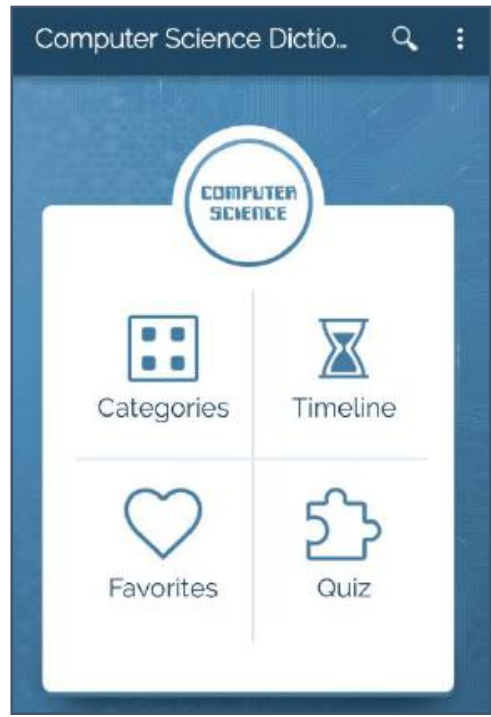

Image 4: Components of Engineering Mobile Dictionary Apps
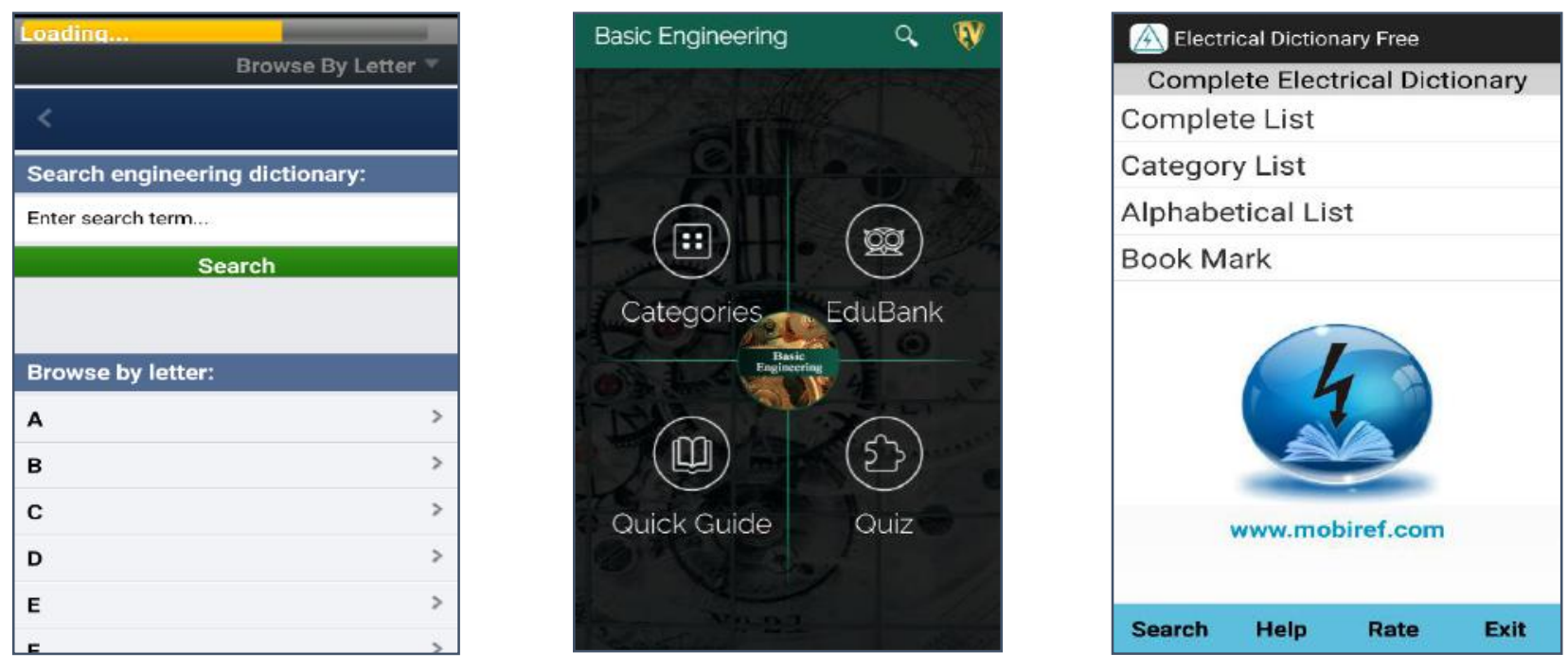

Image 5: Further Components of Specialized Mobile Dictionary Apps

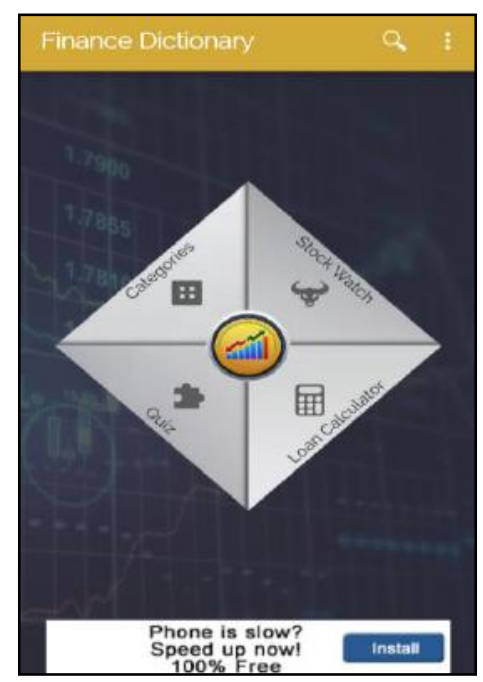

\begin{tabular}{|l|}
\hline Tech Terms a \\
Term of the Day \\
April 06, 2016 \\
VLB \\
Stands for "VESA Local Bus." \\
(VESA stands for "Video \\
Electronics Standards \\
Association"). The VLB, or VL- \\
bus is a hardware interface on \\
the computer's motherboard \\
that is attached to an \\
expansion slot. By connecting a \\
video expansion card to the \\
VLB, you can add extra \\
graphics capabilities to your
\end{tabular}

\begin{tabular}{|l|}
\hline d \\
\hline Android \\
\hline D.O.S. \\
Disk Operater Sci... \\
It is the critical System. \\
component of a \\
computer. It is a \\
software and provides \\
the consistent rules for \\
organizing and storing \\
information. \\
D.P \\
Data Processing. \\
\hline
\end{tabular}

Image 6: Features of Specialized Mobile Dictionary Apps 


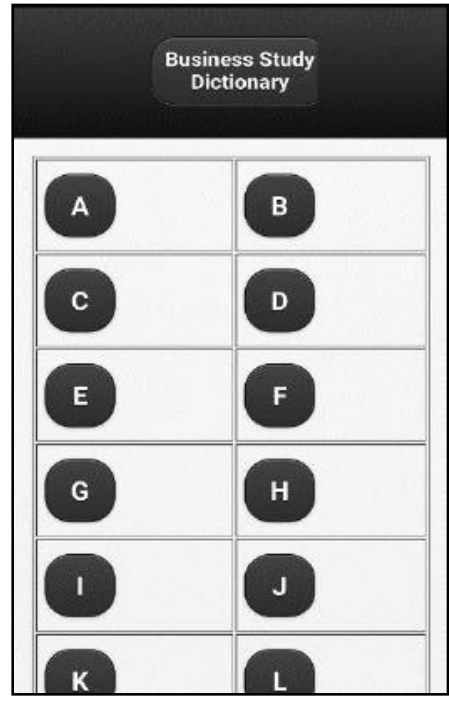

\begin{tabular}{|l|}
\hline E 3 - Business Dictionary \\
\hline TERMS VIDEOS TUTORIALS \\
\hline Search business terms \\
\hline 3 Cs model \\
3-6-3 Rule \\
360-degree evaluation \\
401(k) plan \\
403(b) plan \\
501(c)(3) \\
80/20 rule \\
A \\
A Priori Probability \\
A Share \\
\hline
\end{tabular}

\begin{tabular}{|l|}
\hline E \\
TERMS Business Dictionary \\
\hline Search business terms \\
\hline Absolute Physical Life \\
Absolute Priority \\
Absolute Rate \\
Absolute Return \\
Absolute advantage \\
Absolute poverty \\
Absorb/Absorption \\
Absorbed \\
Absorbed Costs \\
Absorbed account \\
\hline
\end{tabular}

Image 7: Searching Entries of Specialized Mobile Dictionary Apps
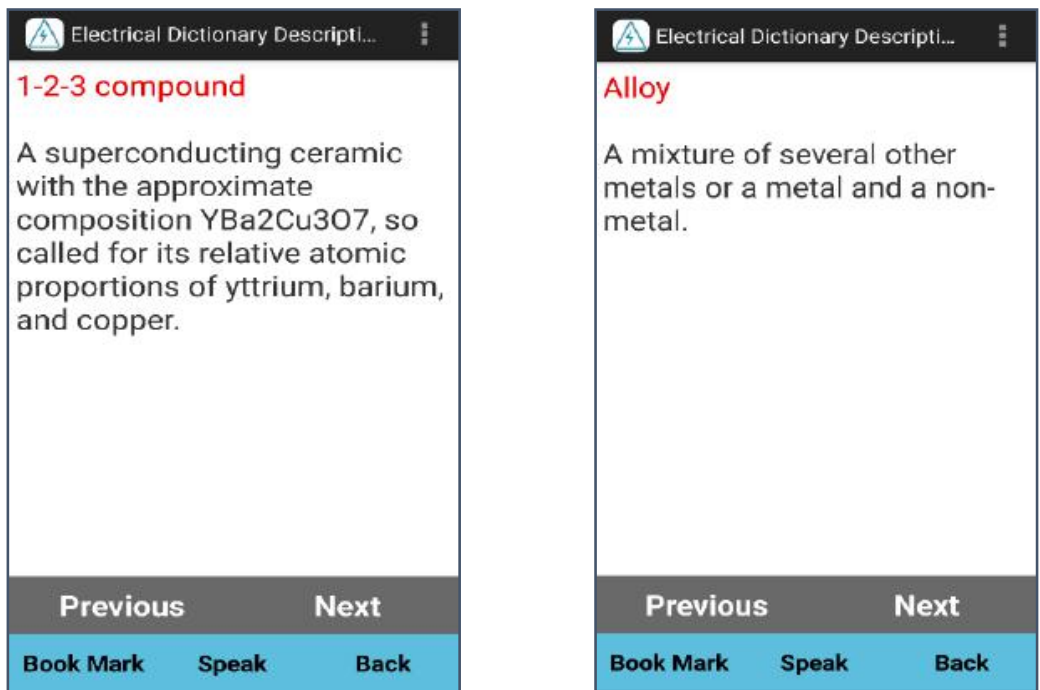

$\leftarrow$ Tech Terms Q
Moodle
Stands for "Modular Object-
Oriented Dynamic Learning
Environment." Moodle is an
open source course
management system, orginally
developed by Martin
Dougiamas. It is used by
thousands of educational
institutions around the world to
provide an organized interface
for e-learning, or learning over
the Internet.

Image 8: Sample Definitions of Technical Terms 